\title{
Dispersal of seeds of Hymenaea courbaril (Fabaceae) in a logged rain forest in the Peruvian Amazonian.
}

\author{
David L. GORCHOV ${ }^{1}$, Jorge M. PALMEIRIM² ${ }^{\text {, Margarita JARAMILLO }}{ }^{3}$, and Cesar F. ASCORRA ${ }^{4}$
}

\begin{abstract}
Seed dispersal of Hymenaea courbaril was studied by following the fate of 585 seeds embedded with small magnets and set in displays in and near a logged strip in rain forest in the Peruvian Amazonian. Mammals took fruits from all displays, which were located in the forest, edge, and cleared strip. Overall removal rates were low - a median of 8.1 fruits / month from displays maintained with 8-10 fruits - but were higher in August than in earlier months. Most fruits were dropped near the display or had their seeds eaten, but $>13 \%$ were successfully dispersed. Most of the dispersed seeds were buried, which increases probability of germination. Maximum dispersal distance of live seeds was $12.1 \mathrm{~m}$ (median $3.1 \mathrm{~m}$ ), but other magnets were transported up to $34 \mathrm{~m}$, indicating seeds were dispersed further, but then eaten. Acouchies (most likely Myoprocta pratti) and agoutis (Dasyprocta fuliginosa) were apparently the main dispersal agents. Dispersal of seeds from the forest into the logged strip was rare, suggesting that although rodents disperse $H$. courbaril, they cannot be relied on for the reseeding this and similar species in recent clearings.
\end{abstract}

\section{KEY WORDS}

Caesalpinioideae, Dasyprocta fuliginosa, Myoprocta pratti, seed predation, forest management

\section{Dispersão de sementes de Hymenaea courbaril (Fabaceae) em uma floresta tropical úmida com exploração madeireira na Amazônia peruana.}

\begin{abstract}
RESUMO
Foi estudada a dispersão de sementes de Hymenaea courbaril, seguindo o destino de 585 sementes marcadas com imãs e expostas a potenciais dispersores, colocadas em agregados no interior e próximo de uma faixa de floresta cortada, na Amazónia peruana. Mamíferos retiraram frutos de todos os agregados, localizados no interior da floresta, na sua borda, e na clareira. As taxas de remoção foram baixas - mediana de 8.1 frutos/mês em agregados mantidos com 8-10 frutos - mas foram mais altas em agosto que nos primeiros meses do ano. A maior parte dos frutos foi abandonada próxima do agregado de origem ou as suas sementes foram consumidas, mas $>13 \%$ foram dispersos com sucesso. A maior parte das sementes dispersas foi enterrada, o que favorece a germinação. A distância máxima de dispersão de sementes vivas foi de $12.1 \mathrm{~m}$ (mediana $3.1 \mathrm{~m}$ ), mas outros imãs foram transportados até $34 \mathrm{~m}$, indicando que as sementes foram dispersas mais longe, mas foram consumidas depois. Cutiaras (muito provavelmente Myoprocta pratti) e cutias (Dasyprocta fuliginosa) parecem ter sido os principais agentes de dispersão. A dispersão de sementes da floresta para o interior da clareira foi rara, sugerindo que apesar de alguns roedores dispersarem $\mathrm{H}$. courbaril, não se pode ficar dependente deles para o repovoamento desta e de outras espécies em clareiras recentes.
\end{abstract}

\section{PALAVRAS-CHAVE}

Caesalpinioideae, Dasyprocta fuliginosa, Myoprocta pratti, predação de sementes, manejo florestal

\footnotetext{
${ }^{1}$ Department of Botany, Miami University, Oxford, Ohio 45056, USA (GorchoDL@muohio.edu)

${ }^{2}$ Centro de Biologia Ambiental e Departamento de Zoologia, Faculdade de Ciências, Universidade de Lisboa, 1700 Lisboa, Portugal

${ }^{3}$ Av. Mariscal Caceres 2022, Iquitos, Peru

${ }^{4}$ Museo de Historia Natural “Javier Prado”, Casilla 140434, Lima 14, Peru, present address: Conservación Internacional Peru, Chinchon 858-A, Lima 27, Peru

"For correspondence: David L. Gorchov, Department of Botany, Miami University, Oxford, Ohio 45056, USA (Fax 513-529-4243; GorchoDL@muohio.edu)
} 


\section{ACTA \\ AMAZONICA}

DISPERSAL OF SEEDS OF HYMENAEA COURBARIL (FABACEAE)

IN A LOGGED RAIN FOREST IN THE PERUVIAN AMAZONIAN

\section{INTRODUCTION}

Natural forest management in the humid tropics can only be economically sustainable if commercially valuable tree species are well-represented in the regeneration that follows felling. One system of natural forest management promoted as sustainable is the strip cut system (Buschbacher, 1990; Hartshorn, 1989). In this system, long, narrow $(30-40 \mathrm{~m})$ strips are clear-cut and all timber is extracted. This width was selected to simulate the diameter typical of natural treefall gaps, which are the principal sites of natural regeneration of many valuable light tropical hardwoods (Hartshorn 1980; 1989). No seedlings are planted in the cleared strips; regeneration is from the seed bank, dispersed seeds, and stump sprouts. Therefore, understanding the dynamics of seed dispersal in the immediate neighborhood of these strips is critical for assessing the sustainability of this system.

Most of the tree species valuable for their timber in Amazon rain forests have large seeds. For example, of 285 forest species listed by Foster (1982), 25\% have seed weights $>1 \mathrm{~g}$, compared to $75 \%$ of species that are in genera with a mill price greater than US $\$ 15 / \mathrm{m}^{3}$ (Peters et al., 1989). Using seed traps placed $50 \mathrm{~cm}$ above the ground to quantify the seed rain in strips cleared by the strip-cut system in the Peruvian Amazon, Gorchov et al. (1993) found that very few large seeds were dispersed into the strips by birds or bats; furthermore, primates rarely entered these strips (E. Notman, pers. comm.). Thus, terrestrial mammals may be the only potentially important carriers of large seeds into logged clearings. Many large-seeded tropical forest trees have seeds that are primarily dispersed by terrestrial mammals (Smythe, 1986). The presence of large artificial clearings is likely to affect the foraging behavior of terrestrial forest mammals, and could influence their role both as seed dispersers and predators. Predation on large seeds by rodents is believed to be greater in treefall gaps than in closed forest (Schupp et al., 1989), although evidence is mixed from the few studies published to date (e.g., Nepstad et al., 1996; Restrepo and Vargas, 1999). Seed predation in logged strips 2 - 3 years following clearing was not different than that in forest understory $15 \mathrm{~m}$ from the edge for either of two tree species, but for one of the species this rate was greater than that in more distant forest, and in the other it was lower (Notman et al., 1996).

Hymenaea courbaril $\mathrm{L}$. is a commercially valuable neotropical tree whose seeds are known to be both dispersed and preyed upon by terrestrial mammals (Janzen, 1983; Hallwachs, 1986; Asquith et al., 1999). To determine the role that terrestrial mammals play in the dispersal of $H$. courbaril into logged strips from adjacent forest in the Peruvian Amazon, we investigated (i) how rapidly terrestrial mammals removed fruits from simulated ground fruit displays; (ii) how far they transported the seeds of the removed fruits; (iii) whether seeds were carried into recently logged strips; and (iv) the fate of the transported seeds.

\section{MATERIALS AND METHODS}

\section{Studied Species}

Hymenaea courbaril (Fabaceae: Caesalpinioideae) is a canopy (sometimes emergent) tree of tropical and subtropical forests of Mexico and the Caribbean through Bolivia and south-central Brazil (Francis, 1990). Seedlings are shade tolerant but grow faster in high light conditions (Gerhardt, 1993). The wood is valuable when sawn and is considered durable, strong, hard, and tough (Patterson, 1988; Francis, 1990). In the Peruvian Amazon, its sawn wood is commercially utilized (Peters et al., 1989). The fruit pulp is edible raw or prepared as a beverage (Francis, 1990). The resinous gum is used in some areas in the manufacture of varnishes or as incense (Schultes and Raffauf, 1990), and both the bark and pulp are used medicinally (Francis, 1990). The fruits are indehiscent legumes (hereafter pods) with a woody exocarp, measuring $4-10 \mathrm{~cm}$ long by $3-7 \mathrm{~cm}$ wide at our study site. In our region most fruits contain one seed, but some contain two or three (mean $\pm \mathrm{SD}=1.17 \pm 0.42$, $n=108$ ). Seeds are c. $1 \times 2 \mathrm{~cm}$ and surrounded by dry, sweet pulp. Pods fall to the ground without breaking open, and if the pod is not opened by animals the seeds are likely to rot (Janzen, 1983). In Central America pods are opened by agoutis (Dasyprocta punctata), pacas (Agouti paca), tapirs (Tapirus bairdii), and probably white-lipped peccaries (Tayassu pecari); these animals eat the pulp and seeds (Hallwachs, 1986). However, agoutis sometimes scatterhoard pods under leaf litter (Janzen, 1983). Capuchin monkeys (Cebus apella) consume the pulp and drop the seeds (Galetti and Pedroni, 1994). In Costa Rica, where agoutis are the only dispersal agent, the probability of mortality during both seed and seedling stages is much lower away from parent trees than under parent trees (Hallwachs, 1986). A study in Venezuela suggested that regeneration of $H$. courbaril in the absence of agoutis was very limited (Asquith et al., 1999).

\section{Study Site}

This research was conducted at the Centro de Investigaciones Jenaro Herrera ( $4^{\circ} 55^{\prime} \mathrm{S} ; 73^{\circ} 40^{\prime} \mathrm{W}$ ), a field station operated by the Instituto de Investigaciones de la Amazonía Peruana and located near the Ucayali River, approximately $130 \mathrm{~km}$ south of Iquitos. Precipitation averages $2521 \mathrm{~mm}$ per year and tends to be lower in June September (Spichiger et al., 1989), but rarely drops below $100 \mathrm{~mm}$ per month (Ascorra et al., 1993).

The experiments reported here were carried out in and near a 30 by $150 \mathrm{~m}$ strip cut in October, 1999 in primary lowland rain forest on high terrace, as part of a broader study on seed dispersal and regeneration. Experiment 1 was initiated in August 1990, 10 months after clearing. At that time, regenerating stems were dense but small, with only 


\section{ACTA AMAZONICA}

0.2 trees $\mathrm{m}^{-2}$ exceeding $2 \mathrm{~m}$, evenly divided between Cecropia spp. seedlings and diverse saplings that survived the felling (unpubl. data). Experiment 2 was initiated in May 1992, 30 months after clearing. By then the vegetation

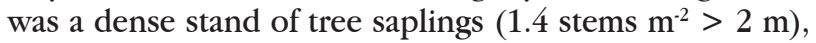
nearly half of which were Cecropia spp. (unpubl. data). This regeneration had a canopy varying from about 6 to $10 \mathrm{~m}$.

\section{Seed Dispersal Experiments}

The basic design of the experiments was to monitor the removal of fruits from displays simulating fruit dropping over a period of weeks from a tree with a small fruit crop. These displays were placed in and near the logged strip. Seeds in these fruits were tagged with magnets, enabling us to assess their fate with a magnetic locator.

Small ( $4.8 \mathrm{~mm}$ diam. x $1.6 \mathrm{~mm}$ thick), disc-shaped, neodymium-iron-boron magnets (Edmund Scientific Co., Barrington, NJ, USA) were inserted into $H$. courbaril seeds. Magnets were painted white and numbered with Sanford Sharpie pens. In 1992, magnets were coated with clear epoxy to reduce oxidation and loss of paint. Magnets were placed inside the seeds by cracking the pod into two parts, drilling a shallow hole into the seed(s), placing a magnet in the hole and sealing it with wax, replacing the seed(s) into the pod, and finally gluing the two pieces of the pod back together with wood glue. A total of 551 marked fruits, containing 585 magnet-embedded seeds, were used in the displays.
To test whether the glue affected removal of fruits by mammals, on 24 June 1992 we set out in primary forest 4 displays of 10 fruits each: 5 unopened and 5 opened and resealed with glued. These displays were checked every 3 days until fruits began to rot (16 July).

To determine if the condition of the pulp influenced the probability of a fruit being taken by mammals, the condition of each fruit used in Experiment 1 was rated using the categories of Hallwachs (1986): 1 = cream-colored pulp, $2=$ brown or white pulp, $3=$ gray or black pulp, and $4=$ no pulp. Discoloration was attributed to fungal growth (Oliveira et al., 1995).

Dispersed magnets were relocated using a Schonstedt GA-52B Magnetic Locator (Alverson and Gómez Diaz, 1989; Iida, 1996; Seiwa et al., 2002). Magnets could be easily detected whether they were inside fruits or on the ground, as long as the tip of the locator was passed within about 30 $\mathrm{cm}$. To ensure that no areas were left unsearched and to facilitate mapping the location of each recovered magnet, we laid out a grid of strings at $7.5 \mathrm{~m}$ intervals. For each recovered magnet we noted whether it was in an intact fruit, in an intact seed, or loose; the condition of the seed or pod, if found; and whether the seed or magnet was buried or in a clump of magnets.

Experiment 1 was initiated on 1 August 1990. Eight fresh fruits with magnets in their seeds were placed at each of two sites (Sites 1 and 2) in the forest, both about $3 \mathrm{~m}$ from the edge of the strip (figure 1). These were checked

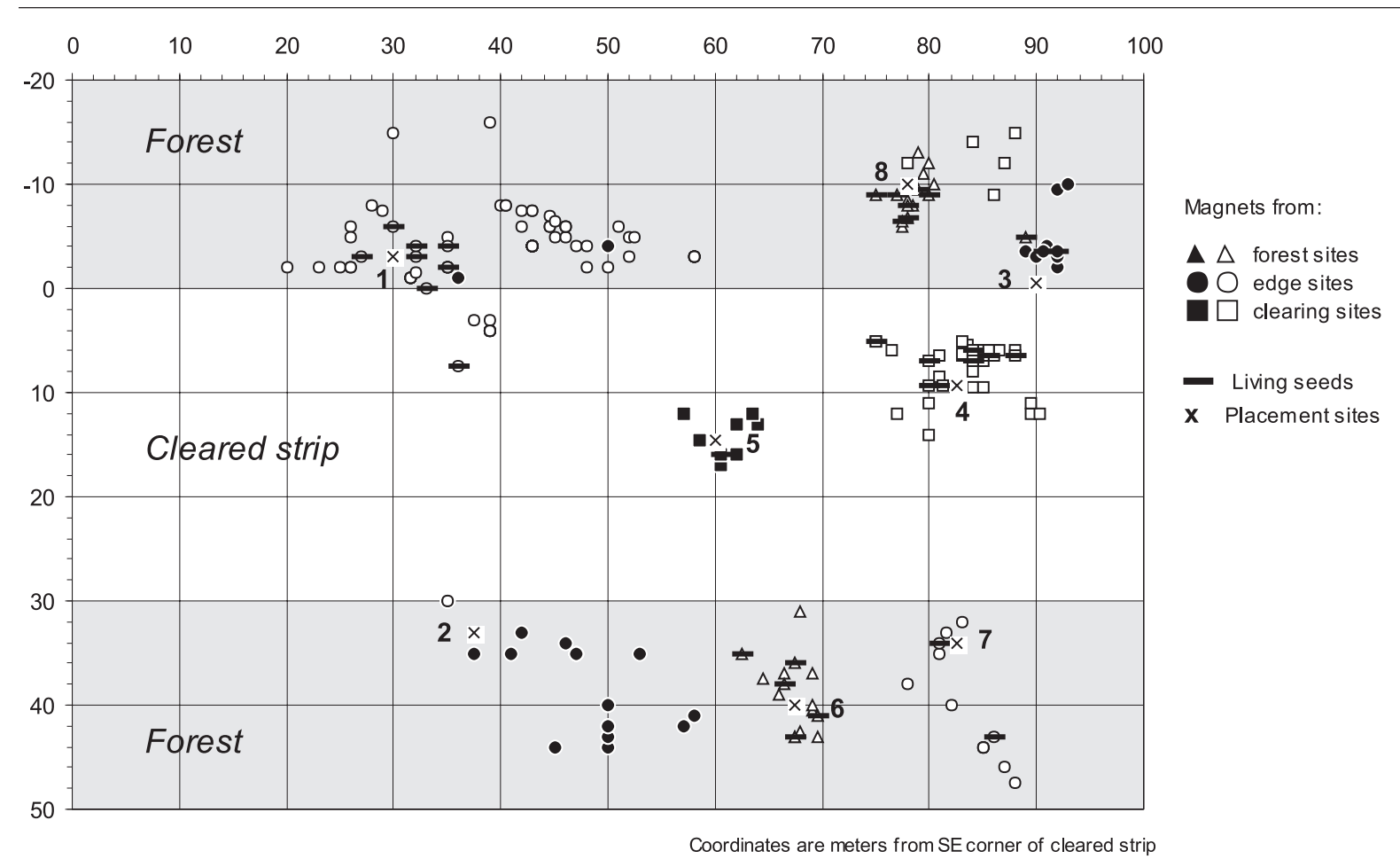

Figure 1 - Schematic representation of the cleared strip in Jenaro Herrera, Peru, showing locations of the eight fruit placement sites and of magnets originating from each site. 
nearly every day through August 29, and fruits that were moved by mammals were replaced daily. A total of 128 fruits were placed: 109 had magnets in 1 seed, 16 had magnets in 2 seeds, and 3 had magnets in 3 , for a total of 150 magnet-embedded seeds. Between 13 and 21 September an area of about $90 \mathrm{~m} \times 60 \mathrm{~m}$, centered roughly on the displays, was thoroughly searched to locate the magnets dispersed from these two sites.

Experiment 2 was carried out in the same area in 1992 and involved two sites in each of three habitats: forest, edge, and strip (figure 1). Sites $3-5$ were studied beginning 31 May, and sites $6-8$ on 18 June. In this experiment, 10 fresh fruits were initially placed in each display. They were checked every three days through August 31, and all the missing fruits were replaced at the time of these visits. Beginning 27 June, fruits that had remained unopened for 12 days were also replaced, on the assumption that these fruits might be ignored because their pulp had rotted. Of the 423 fruits used, 12 had 2 seeds (each with a magnet) and the remainder were singleseeded, for a total of 435 magnet-embedded seeds. Between 4 and 14 September an area of $67.5 \mathrm{mx} 45 \mathrm{~m}$ was thoroughly searched with the magnetic locator.

\section{Fate of the handled seeds}

When a magnet was recovered alone and not adjacent to a seedling, we inferred that the seed had been eaten. However, it is possible that the seed was dispersed alive and then either rotted, fell prey to a secondary seed predator, or germinated and was then eaten by a seedling predator. Hence, by considering these seeds to have been eaten, we may be overestimating seed predation and underestimating seed dispersal by the mammals responsible for the movement of the seed; our "dispersal rates" actually represent the number of seeds that were transported and remained alive, as seed or seedling, until the end of the study.

\section{Statistical Analyses}

We used G tests (Sokal and Rohlf, 1995) to test for differences in fates of fruits differing in pulp condition and, in Experiment 2, for differences in the fates of fruits placed at the three different habitats. However, the statistical findings should be interpreted with caution because individual fruits were not completely independent.

\section{RESULTS}

\section{Removal rates}

Our method of opening and resealing $H$. courbaril fruits did not affect handling by mammals. There was no significant difference in the proportion removed between the 20 glued fruits (60\%) and the 20 unopened fruits ( $75 \%$; $G_{\text {adj }}=0.99$ ). Furthermore, time to removal for the glued fruits was similar to that for the controls $(10.1 \pm 4.5$ days vs. $12.2 \pm 3.5$ days, $t=1.3, d f=25, P>0.20$ ).

Fruits were dispersed from the displays at rates that varied considerably from site to site, but removal was generally slow (figure 2); and only 293 of the 551 fruits were handled. Only on 3 of c. 204 checks of individual fruit displays had mammals removed all of the 8-10 fruits available during the 1-3 day interval that lapsed between checks. Only on 24 occasions had $50 \%$ of the fruits in a display been removed. Median removal rates per site for the eight sites was 8.1 fruits/month. However, removal was faster in the August 1990 experiment, when the median was 71 fruits/ month (figure 2a). During the 1992 experiment, removal tended to be higher in August (median 14.5 fruits/month) than in June and July (median 1.75 fruits/month; figure 2b).

Mammals took fruits from all the displays, regardless of location. However, in Experiment 2 the percentage of fruits handled was greater in the strip displays (46\%) than in the edge $(27 \%)$ or forest $(32 \%)(G=13.4, d f=2, P<0.005)$. The two sites used in the 1990 experiment yielded the highest removal rates.
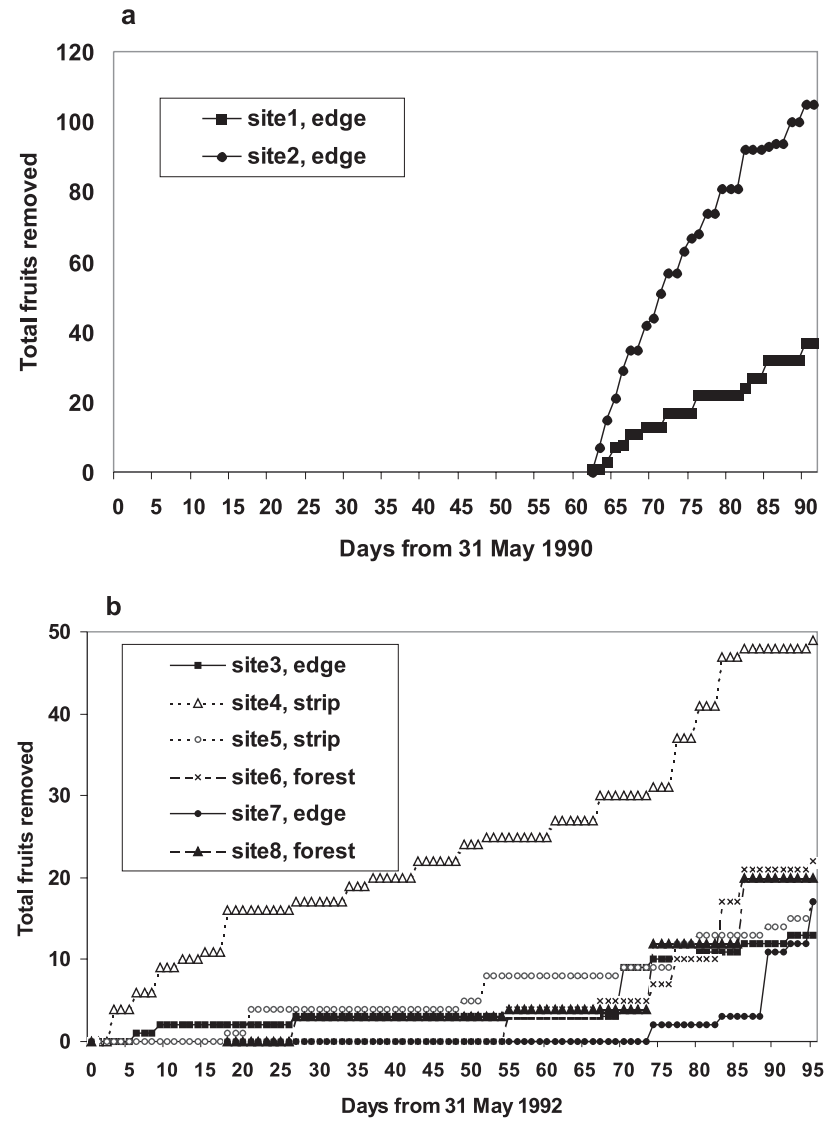

Figure 2 - Cumulative number of the fruits taken from each of the sites (displays). a. Experiment 1; both displays were initiated 1 Aug. 1990 (= day 62). b. Experiment 2; displays at sites 3, 4, and 5 were initiated on 31 May 1992 and those at sites 6, 7, and 8 were initiated on 18 June 1992. 


\section{ACTA AMAZONICA}

Pulp condition did not affect the proportion of seeds handled by mammals $(\mathrm{G}=0.88, \mathrm{df}=2, \mathrm{P}>0.5)$ nor the proportion of handled seeds that were dispersed $(G=1.02$ $\mathrm{df}=2, \mathrm{P}>0.5$; category 4 was excluded because only 4 fruits fell in this category).

\section{Fate of the handled fruits}

Of the 142 fruits handled (eaten or moved) in Experiment 1, we recovered seeds embedded with magnets from 119 (84\%), all of these $>1 \mathrm{~m}$ from any display site (Table 1$)$. Of the 120 magnets recovered, 37 had lost their number due to corrosion, so we could not determine at which site they had been placed. We calculated movement distances for these seeds using the assumption that they had been placed at the site closest to the recovery point. In Experiment 2, the 151 handled fruits contained 155 seeds with magnets; we recovered 137 of these (88\%), of which 104 were $>1 \mathrm{~m}$ from the display site (Table $1)$. The proportion of seed recovered $<1 \mathrm{~m}$, recovered $>1 \mathrm{~m}$, or not recovered, was similar among the strip, edge, and forest habitats in Experiment 2 ( $\mathrm{G}=0.64$, df $=2, \mathrm{P}>0.95)$. We considered $13.3 \%$ of the recovered seeds to be successful dispersal events, because the magnets were either in intact fruits (10) or in intact seeds (24) that had been transported > $1 \mathrm{~m}$ from the display site. Eleven of these seeds were already germinating when they were found. Successfully dispersed seeds were found in forest, edge, and strip sites. Dispersal was highest in the two forest sites (23\% and 36\%). In all eight fruit displays, a majority of the fruits handled by mammals either had their seeds eaten or were dropped within $1 \mathrm{~m}$ of the display site, and therefore were considered not dispersed. However, as explained above, these estimates of successful dispersal by mammals could be somewhat underestimated.

Twenty-two of the 34 magnets dispersed inside intact fruits or seeds were found buried in soil or leaf litter, and some of the remaining were under logs or roots. Of the 189 free magnets, 98 were buried and 10 were found in mammalian excrements.

\section{Dispersal distances}

Overall median dispersal distances of retrieved magnets was $5.4 \mathrm{~m}$ (mean $8.7 \pm$ standard deviation 6.9) (table I). Dispersal distances tended to be greater for magnets found loose (median $7.6 \mathrm{~m}$, max. $34 \mathrm{~m}$, mean $4.1 \pm 3.0$ ) than for magnets in live seeds (median $3.1 \mathrm{~m}$, max. $12.1 \mathrm{~m}$, mean $9.5 \pm 7.1$ ) (figure 3). Maximum transport distances for live seeds and loose magnets were 12.1 and $34 \mathrm{~m}$, respectively.

\section{Transport of magnets into the cleared strip}

The spatial dispersal patterns of the magnets in relation to the cleared strip are shown on figure 1 . All of the magnets originating in the two forest sites were retrieved in the forest.

Table 1 - Fate of magnets in Hymenaea courbaril seeds handled by terrestrial mammals at the eight experimental fruit displays in and near a logged strip in Jenaro Herrera, Peru. See Methods for number of fruits that had $\geqslant 2$ seeds and magnets.

\begin{tabular}{|c|c|c|c|c|c|}
\hline \multirow{2}{*}{ Year \& Site } & \multirow{2}{*}{$\begin{array}{c}\text { Total } \\
\text { handled } \\
\text { seeds }\end{array}$} & \multirow{2}{*}{$\begin{array}{l}\text { Recovered near } \\
\text { display }(<1 \mathrm{~m})\end{array}$} & \multicolumn{2}{|c|}{ Recovered away from display } & \multirow{2}{*}{$\begin{array}{l}\text { Median dispersal } \\
\text { distance }^{\mathrm{b}}(\mathrm{m})\end{array}$} \\
\hline & & & total & in live seed $^{a}$ & \\
\hline \multicolumn{6}{|l|}{ Forest } \\
\hline Site 6 (1992) & 22 & 4 & 15 & $5(23 \%)$ & 3.0 \\
\hline Site 8 (1992) & 22 & 6 & 15 & $8(36 \%)$ & 2.7 \\
\hline Subtotal & 44 & 10 & 30 & $13(30 \%)$ & 3.0 \\
\hline \multicolumn{6}{|l|}{ Edge } \\
\hline Site 1 (1990) & 37 & 0 & 32 & $0(0 \%)$ & - \\
\hline Site 2 (1990) & 105 & 0 & 87 & $8(8 \%)$ & 3.6 \\
\hline Site 3 (1992) & 16 & 5 & 11 & $3(19 \%)$ & 3.6 \\
\hline Site 7 (1992) & $19^{c}$ & 3 & 12 & $2(11 \%)$ & 5.6 \\
\hline Subtotal & 177 & 8 & 142 & $13(9 \%)$ & 3.6 \\
\hline \multicolumn{6}{|l|}{ Strip } \\
\hline Site 4 (1992) & $56^{d}$ & $8^{c}$ & $43^{c}$ & 7 (12\%) & 3.4 \\
\hline Site 5 (1992) & $20^{c}$ & 7 & 8 & $1(5 \%)$ & 1.6 \\
\hline Subtotal & 76 & 15 & 51 & $8(11 \%)$ & 3.0 \\
\hline TOTAL & 297 & 33 & 223 & 34 (15\%) & 3.1 \\
\hline
\end{tabular}

a) percentages based on the number of seeds with magnets in fruits that were eaten or moved; b) of live seeds; c) includes 2 magnets in same fruit; d) includes 2 magnets in each of 2 fruits 


\section{ACTA AMAZONICA}

DISPERSAL OF SEEDS OF HYMENAEA COURBARIL (FABACEAE) IN A LOGGED RAIN FOREST IN THE PERUVIAN AMAZONIAN
Likewise, the great majority (53) of magnets taken from the fruit displays located inside the strip were dropped in the cleared area; only six were transported into the adjacent forest. In the case of the displays at the edge there was a clear pattern: in each of the four cases far more magnets were moved into the forest than towards the strip. The binomial probability of this occurring by chance was $P=0.06$.

From each experiment we recovered one magnetembedded intact seed in the strip from a fruit that had been placed in an edge display.

\section{DISCUSSION}

\section{Removal rates}

The tendency for slower fruit removal in 1992 compared to 1990 could be due to several factors. The total number of fruits maintained in displays was larger in 1992 (60 vs. 16), potentially satiating the individual rodents whose home ranges included the displays, which were all within 0.15 ha. Removal may have been slower in 1992 due to lower rodent densities or higher food availability. Alternatively the slower removal rate could be due to the earlier start of the experiment; removal rates increased later in the experiment (August) to rates approaching those of the August 1990 experiment. Removal may be slow early in the dry season because dasyproctid rodents (agoutis and acouchies) tend to minimize hoarding during seasons of fruit scarcity (Smythe, 1978; 1986; Dubost, 1988). In fact, H. courbaril seeds are ideal to hoard because they suffer relatively low rates of post-dispersal predation by insects (Terborgh et al., 1993). Forget (1993) found that as seeds of Dipteryx panamensis became more abundant over its fruiting season,

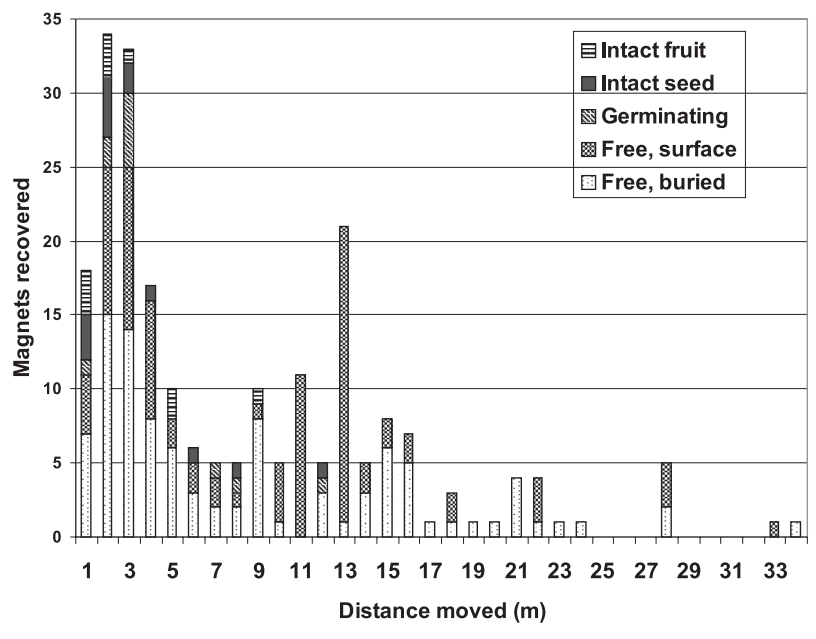

Figure 3 - Number of magnets recovered at different distances from their placement site, grouped by the condition they were found. " 1 " refers to seeds recovered $>1 \mathrm{~m}$ to $<2 \mathrm{~m}$ from placement site, etc. Data pooled from Experiment 1 (1990) and 2 (1992). agoutis hoarded them at a higher rate and consumed them at a lower rate. Forget (1996) discussed the complexity of seasonal patterns in scatterhoarding and reported both low predation and low dispersal of Carapa procera seeds by these rodents during the period of peak food availability.

The fact that the removal rates from the two sites inside the strip were within the range of those in the forest and edge show that potential dispersers of $H$. courbaril forage within the strips. However, we only placed seeds in these sites in 1992, when the density of cover in the strip was already quite high. During the same period in 1992 Notman et al. (1996) found faster seed removal at the edge of the strip than in the forest or strip center for Macoubea guianensis, but no spatial pattern for Pouteria sp. In a Mexican rain forest fruit and seed removal by terrestrial mammals was higher in mature forest than in gaps (Sánchez-Cordero and MartínezGallardo, 1998), but in an Australian rain forest removal was higher in forests and gaps than at forest edges, and lowest in pastures (Osunkoya, 1994). Predation on Tachigali versicolor seeds was greater in young than old forest on Barro Colorado Island (Forget et al., 1999).

Removal rates of $H$. courbaril fruits were within the range reported for other large-seeded Neotropical seeds eaten or dispersed by rodents in mainland South America. In French Guiana 10-96\% of Vouacapoua americana seeds, placed in sets of 25, were removed over 1 month (Forget, 1990 ) and at our site in Peru $20-40 \%$ of Pouteria sp. seeds (sets of 5) were removed over 23 days but close to $100 \%$ of Macoubea guianensis seeds (sets of 10) were removed over 21 days (Notman et al., 1996). Removal rates were higher on Barro Colorado Island, Panama, where nearly all Scheelea zonensis seeds were removed within 7 days (Forget et al., 1994 ) and $85 \%$ of Gustavia superba were removed within 28 days (Forget, 1992). DeSteven and Putz (1984) and Sork (1987) found seed removal of Dipteryx panamensis and Gustavia superba, respectively, to be much higher on BCI than on the mainland Gigante Peninsula, and attributed this to higher populations of seed predator/disperser mammals.

\section{Fate of the handled fruits}

The fact that such a high proportion of the dispersed fruits and seeds were buried is significant because burial substantially increases the chances of germination of both free seeds and seeds inside pods (Asquith et al., 1999). The seeds that had germinated by the end of our experiments represented only $4.3 \%$ of the total number of seeds with ascertained fates, but they were $32 \%$ of those seeds which were found alive. This percentage would almost certainly increase with time, because many of the seeds were still in condition to germinate when they were found. Therefore, mammals left the seeds in sites that were suitable for germination, although it is possible that germination was hastened by drilling and magnet placement. Our results show that seeds can germinate both in the forest and in the cleared area. 


\section{ACTA AMAZONICA}

DISPERSAL OF SEEDS OF HYMENAEA COURBARIL (FABACEAE) IN A LOGGED RAIN FOREST IN THE PERUVIAN AMAZONIAN

\section{Dispersal distances}

We relocated a substantially greater proportion of magnets than in other studies of dispersal of seeds embedded with magnets (Iida, 1996; Seiwa et al., 2002). The majority of magnets not recovered were most likely moved outside of the area searched, as we tried to pass the magnetic locator over every piece of ground. Therefore, our estimates of the median distances for both dispersed and eaten seeds are likely to be conservative.

Our finding that intact seeds were not dispersed as far as magnets recovered without seeds, suggests that more distantly dispersed seeds were more likely to be consumed, or that the animals responsible for the longer dispersal distances were predators and not hoarders. The short dispersal distances in this study were similar to those reported for dispersal of $H$. courbaril by agoutis in Venezuela (Asquith et al., 1999) and in Costa Rica during the dry season (Hallwachs, 1986). However, in Costa Rica during the wet season, dispersal distances were greater $($ median $=55 \mathrm{~m})$. The short median dispersal distances were also similar to those of Gustavia superba (Lecythidaceae) by Dasyprocta punctata on Barro Colorado Island (Forget, 1992) and Vouacapoua americana (Fabaceae) by Dasyprocta leporina and Myoprocta exilis in French Guiana (Forget, 1990). Comparisons are complicated as area searched differed among these studies.

\section{Dispersal into the cleared strip}

The seed shadows resulting from the display sites placed just $10 \mathrm{~m}$ inside the forest suggested that the presence of the cleared strip did not influence the direction of dispersal inside the forest. In fact, terrestrial mammals appeared to be efficient at dispersing seeds up to the edge of the strip. However, they did not bring seeds from the forest edges into the relatively open environment of the logged strip, suggesting that they do not promote the reestablishment of $H$. courbaril following strip-clearing. This was true even in our 1992 experiment, when the strip was already covered by a dense stand of tree saplings. This contrasts with Seiwa et al.'s (2002) finding that wood mice dispersed some Castanea crenata seeds into small (6 $\mathrm{m}$ radius) treefall gaps. However, most of the $H$. courbaril seeds taken from the displays located within the strip were left there, and a few seeds were brought in from the edges to the strip, suggesting that different rodent species (or individuals) were taking seeds from strip vs. forest displays. Rodent dispersal of seeds into logged strips is likely to increase as the regeneration ages due to greater activity of terrestrial mammals.

\section{Identity of dispersers}

Two spiny rats (Proechimys simonsi) were captured in live traps baited with opened $H$. courbaril fruits near the cleared strip, and consumed its seeds while held in captivity.
However, like several other small rodents found in the area (Notman, 2000), they seem to be unable to open the fruits. Similarly, captive P. semispinosus in Panama ignored intact H. courbaril fruits but ate free seeds and seeds within old legumes that had degraded (Adler, 1995). Consequently, spiny rats are unlikely to be responsible for the observed dispersal events, but may instead have preyed on seeds cached by other mammals. Large squirrels could probably open $\mathrm{H}$. courbaril pods but their foraging appears centered on palm swamps (Notman, 2000). On three dates acouchy (most likely Myoprocta pratti) footprints were found on a layer of clay placed in one of the display sites. On each of these dates, one or two fruits were missing from the display. Of the 5 magnets in these fruits, 4 were later found buried in soil $2.5-21.7 \mathrm{~m}$ away and one was found in an intact fruit $2.7 \mathrm{~m}$ away. These are typical of the recovery conditions and locations of magnets from $\mathrm{H}$. courbaril seeds in our experiments, suggesting that acouchies could have been primary dispersers. Although we have no direct evidence that the single seeds were also buried by acouchies, this behavior has been reported for other species of the genus (Morris, 1962). However, agoutis (Dasyprocta fuliginosa) were also observed in and near the strip. Other species of Dasyprocta have been reported as the main dispersers of H. courbaril in other regions (Hallwachs, 1986; Asquith et al. 1999) and it is likely that they were responsible for some of the dispersal events we documented.

\section{Implications for management}

Dasyproctid rodents appear to be the major dispersers of $H$. courbaril, and seedling recruitment of the species may be limited in the absence of these large rodents. Our results suggest that these rodents continue to disperse $\mathrm{H}$. courbaril in forested areas in the immediate vicinity of cleared strips. However, in our experiments, seeds were rarely moved to the interior of logged strips from the edge, and never from the forest, suggesting that terrestrial mammals cannot be relied on to efficiently disperse seeds of forest trees into logged strips during the first years after clearing. Consequently, if rapid regeneration of large-seeded commercial trees is necessary for the success of a forest management system, it is necessary to minimize damage to advanced regeneration (seedlings and saplings) during felling and log extraction, effectively manage stump sprouts, or invest in artificial regeneration (direct seeding or planting seedlings).

\section{ACKNOWLEDGEMENTS}

This research was supported by a grant from the World Wildlife Fund - U.S. to DLG and JMP and by Grant No. 7.228, Program in Science and Technology Cooperation, USAID to John Terborgh, David Gorchov, and Fernando Cornejo. The Peruvian Amazon Research Institute (IIAP) kindly allowed the use of the Jenaro Herrera Research Station (CIJH) and its facilities, and we especially 


\section{ACTA \\ AMAZONICA}

DISPERSAL OF SEEDS OF HYMENAEA COURBARIL (FABACEAE)

IN A LOGGED RAIN FOREST IN THE PERUVIAN AMAZONIAN acknowledge the support of the CIJH Director, Manuel Isuiza. Fernando Cornejo, Italo Melendez, Ken Guttman, and Miguel Ortega assisted in various aspects of the project. Valuable comments on earlier drafts of this manuscript were provided by Evan Notman, Pierre-Michel Forget, Tad Theimer, and anonymous reviewers.

\section{LITERATURE CITED}

Adler, G.H. 1995. Fruit and seed exploitation by Central American Spiny Rats, Proechimys semispinosus. Studies of the Neotropical Fauna and Environment, 30 (4): 237-244.

Alverson, W.S.; Gómez Diaz, A. 1989. Measurement of dispersal of large seeds and fruits with a magnetic locator. Biotropica, 21: 61-63.

Ascorra, C.F.; Gorchov, D.L.; Cornejo, F. 1993. The bats from Jenaro Herrera, Loreto, Peru. Mammalia, 57(4): 533-552.

Asquith, N.M.; Terborgh, J.; Arnold, A.E.; Riveros, C.M. 1999. The fruits the agouti ate: Hymenaea courbaril seed fate when its disperser is absent. Journal of Tropical Ecology, 15: 229-235.

Buschbacher, R.J. 1990. Natural forest management in the humid tropics: ecological, social, and economic considerations. Ambio, 19(5): 253-258.

DeSteven, D.; Putz, F.E. 1984. Impact of mammals on early recruitment of a tropical canopy tree, Dipteryx panamensis, in Panama. Oikos, 43(2): 207-216.

Dubost, G. 1988. Ecology and social life of the red acouchy, Myoprocta exilis; comparison with the orange-rumped agouti, Dasyprocta leporina. Journal of Zoology, 214(1):107-124.

Forget, P.-M. 1990. Seed-dispersal of Vouacapoua americana (Caesalpiniaceae) by caviomorph rodents in French Guiana. Journal Tropical Ecology, 6: 459-468.

Forget, P.-M. 1992. Seed removal and seed fate in Gustavia superba (Lecythidaceae). Biotropica, 24(3): 408-414.

Forget, P.-M. 1993. Post-dispersal predation and scatterhoarding of Dipteryx panamensis (Papilionaceae) seeds by rodents in Panama. Oecologia, 94: 255-261.

Forget, P.-M. 1996. Removal of seeds of Carapa procera (Meliaceae) by rodents and their fate in rainforest in French Guiana.Journal of Tropical Ecology, 12: 751-761.

Forget, P.-M.; Kitajima, K.; Foster, R. 1999. Pre- and post-dispersal seed predation in Tachigali versicolor (Caesalpiniaceae): effects of timing of fruiting and variation among trees. Journal of Tropical Ecology, 15: 61-81.

Forget, P.-M.; Munoz, E.; Leigh, E.G. Jr. 1994. Predation by rodents and bruchid beetles on seeds of Scheelea palms on Barro Colorado Island, Panama. Biotropica, 26(4): 420-426.

Foster, R.B. 1982. The seasonal rhythm of fruitfall on Barro Colorado Island. In: Leigh, E.G. Jr.; Rand, A.S.; Windsor, D.M. (Eds). The Ecology of a Tropical Forest: Seasonal Rhythms and Long-term Changes. Smithsonian Institution Press, Washington, USA. p.151-172.

Francis, J.K. 1990. Hymenaea courbaril (L.). USDA Forest Service. SO-ITF-SM-27
Galetti, M.; Pedroni, F. 1994. Seasonal diet of capuchin monkeys (Cebus apella) in a semideciduous forest in south-east Brazil. Journal of Tropical Ecology, 10: 27-39.

Gerhardt, K. 1993. Tree seedling development in tropical dry abandoned pasture and secondary forest in Costa Rica.Journal of Vegetation Science, 4: 95-102.

Gorchov, D.L.; Cornejo, F.; Ascorra, C.; Jaramillo, M. 1993. The role of seed dispersal in the natural regeneration of rain forest after strip-cutting in the Peruvian Amazon. Vegetatio, 107/ 108: 339-349.

Hallwachs, W. 1986. Agoutis (Dasyprocta punctata): the inheritors of guapinol (Hymenaea courbaril: Leguminosae). In: Estrada, A.; Fleming, T.H. (Eds). Frugivores and Seed Dispersal. W. Junk Publishers, Dordrecht. p.285-304.

Hartshorn, G.S. 1980. Neotropical forest dynamics. Biotropica, 12 Suppl.: 2330.

Hartshorn, G.S. 1989. Application of gap theory to tropical forest management: natural regeneration on strip clear cuts in the Peruvian Amazon. Ecology, 70(3): 567569.

Iida, S. 1996. Quantitative analysis of acorn transportation by rodents using magnetic locator. Vegetatio, 124: 39-43

Janzen, D.H. 1983. Hymenaea courbaril: (Guapinol, Stinking Toe). In: Janzen, D.H. (Ed). Costa Rican Natural History. University of Chicago Press, Chicago, USA. p.253-256.

Morris, D. 1962. The behavior of the green acouchi (Myoprocta pratti), with special reference to scatter hoarding. Proceedings. Zoological Society of London, 139: 701-733.

Nepstad, D.C.; Uhl, C.; Pereira, C.A.; Cardosa da Silva, J.M. 1996. A comparative study of tree establishment in abandoned pasture and mature forest in eastern Amazonia. Oikos, 76: 25-49.

Notman, E.; Gorchov, D.L.; Cornejo, F. 1996. Effect of distance, aggregation, and habitat on levels of seed predation for two mammal-dispersed neotropical rain forest tree species. Oecologia, 106: 221-227.

Notman, E.M. 2000. The influence of seed characters on postdispersal seed predation by vertebrates and invertebrates in mature and regenerating Peruvian lowland tropical forest. Ph.D. dissertation, Miami University, Oxford, Ohio, USA.

Oliveira, P.S.; Galetti, M.; Pedroni, F.; Morellato, L.P.C. 1995. Seed cleaning by Mycocepurus goeldii ants (Attini) facilitates germination in Hymenaea courbaril (Caesalpiniaceae). Biotropica, 27(4): 518-522.

Osunkoya, O.O. 1994. Postdispersal survivorship of north Queensland rainforest seeds and fruits: Effects of forest, habitat and species. Australian Journal of Ecology, 19(1): 52-64.

Patterson, D. 1988. Commercial Timbers of the World (5th edition). Gower Technical Press, Aldershot, England.

Peters, C.M.; Gentry, A.H.; Mendelsohn, R.O. 1989. Valuation of an Amazonian rainforest. Nature, 339: 655-656.

Restrepo, C.; Vargas, A. 1999. Seeds and seedlings of two neotropical montane understory shrubs respond differently to anthropogenic edges and treefall gaps. Oecologia, 119: 419-426. 
Sánchez-Cordero, V.; Martínez-Gallardo, R. 1989. Postdispersal fruit and seed removal by forest-dwelling rodents in a lowland rainforest in Mexico.Journal of Tropical Ecology, 14: 139-151.

Schultes, R.E.; Raffauf, R.F. 1990. The Healing Forest. Medicinal and Toxic Plants of the Northwest Amazonia. Dioscorides Press, Portland, Oregon, USA. 484 p.

Schupp, E.W.; Howe, H.F.; Augspurger, C.K.; Levey, D.J. 1989. Arrival and survival in tropical treefall gaps. Ecology, 70(3): 562-564.

Seiwa, K.; Watanabe, A.; Irie, K.; Kanno, H.; Saitoh, T.; Akasaka, S. Impact of site-induced mouse caching and transport behaviour on regeneration in Castanea crenata.Journal of Vegetation Science, 13: 517-526.

Smythe, N. 1978. The natural history of the Central American agouti (Dasyprocta punctata). Smithsonian Contributions to Zoology, 257: 1-52.

Smythe, N. 1986. Competition and resource partitioning in the guild of Neotropical, terrestrial, frugivorous mammals. Annual Review of Ecology and Systematics, 17: 169-188.
Sokal, R.R.; Rohlf, F.J. 1995. Biometry. The principles and practice of statistics in biological research (3rd edition). W.H. Freeman, New York, USA. 859 p.

Sork, V.L. 1987. Effects of predation and light on seedling establishment in Gustavia superba. Ecology, 68(5): 1341-1350.

Spichiger, L.; Méroz, J.; Loizeau P.-A.; Stutz de Ortega, L. 1989. Contribución a la Flora de la Amazonía Peruana. Los Árboles del Arborétum Jenaro Herrera. Vol. 1. Conservatoire et Jardin Botaniques de Genève. 359 p.

Terborgh, J.; Losos, E.; Riley, M.P.; Bolaños Riley, M. 1993. Predation by vertebrates and invertebrates on the seeds of five canopy tree species of an Amazonian forest. Vegetatio, 107/108: 375-386.

\section{RECEBIDO EM 14/10/2002 \\ ACEITO EM 12/03/2004}


